\title{
Recommendations of the Latin American Thyroid Society on diagnosis and management of differentiated thyroid cancer
}

\author{
Recomendações da Sociedade Latino-Americana de Tireoide para \\ diagnóstico e manejo do carcinoma diferenciado de tireoide
}

Fabián Pitoia', Laura Ward ${ }^{2}$, Nelson Wohllk ${ }^{3}$, Celso Friguglietti ${ }^{4}$, Eduardo Tomimori ${ }^{5}$, Alicia Gauna ${ }^{6}$, Rosalinda Camargo ${ }^{5}$, Mario Vaisman 7 , Rubén $\mathrm{Harach}^{8}$, Fernando Munizaga ${ }^{3}$, Sandro Corigliano ${ }^{9}$, Eduardo Pretell ${ }^{9}$, Hugo Niepomniszcze ${ }^{1}$

\footnotetext{
'División Endocrinologia, Hospital de Clínicas, Universidad de Buenos Aires (UBA), Buenos Aires, Argentina* ${ }^{2}$ Laboratório de Genética Molecular do Câncer, Faculdade de Ciências Médicas (FCM), Universidade Estadual de Campinas (Unicamp)، Campinas, SP, Brasil*

${ }^{3}$ Sección Endocrinologia, Universidad do Chile, Santiago do Chile, Chile ${ }^{4}$ Departamento de Cabeça e Pescoço, Faculdade de Medicina, Universidade de Santo Amaro (Unisa), São Paulo, SP, Brasil ${ }^{5}$ Divisão de Endocrinologia, Faculdade de Medicina, Universidade de São Paulo (USP), São Paulo, SP, Brasil ${ }^{6}$ División Endocrinologia, Hospital Ramos Mejía, Buenos Aires, Argentina ${ }^{7}$ Serviço Endocrinologia, Universidade Federal do Rio de Janeiro (UFRJ), Rio de Janeiro, RJ, Brasil ${ }^{8}$ Servicio de Patología, Hospital Oñativia, Salta, Argentina 9 Instituto de Investigaciones de la Altura, Universidad Peruana Cayetano Heredia, Lima, Perú

* Fabián Pitoia and Laura Ward contributed equally to this work

Correspondence to:

Fabián Pitoia

Córdoba 2351 5to Piso - Buenos

Aires, Argentina

fpitoia@intramed.net

Received in Apr/13/2009

Accepted in Aug/11/2009
}

\begin{abstract}
The aims of these recommendations were to develop clinical guidelines for evaluation and management of patients with differentiated thyroid cancer applicable to Latin American countries. The panel was composed by 13 members of the Latin American Thyroid Society (LATS) involved with research and management of thyroid cancer from different medical centers in Latin America. The recommendations were produced on the basis of the expert opinion of the panel with use of principles of Evidence-Based Medicine. Following a group meeting, a first draft based on evidences and the expert opinions of the panel was elaborated and, later, circulated among panel members, for further revision. After, this document was submitted to the LATS members, for commentaries and considerations, and, finally, revised and refined by the authors. The final recommendations presented in this paper represent the state of the art on management of differentiated thyroid cancer applied to all Latin American countries. Arq Bras Endocrinol Metab. 2009;53(7):884-97.
\end{abstract}

Keywords

'Thyroid cancer; thyroid ultrasonography; radioiodine therapy; thyroglobulin; consensus

\section{RESUMO}

Estas recomendações tiveram por objetivo o desenvolvimento de diretrizes para avaliação e manejo de pacientes com câncer diferenciado da tiroide em países latino-americanos. Um painel composto por 13 membros da Sociedade Latino-Americana de Tireoide (SLAT) - que estavam envolvidos em pesquisas, e eram peritos no cuidado do paciente com câncer da tiroide e provenientes de diferentes centros médicos latino-americanos - utilizou os princípios da Medicina Baseada em Evidências para produzir esse consenso. Após uma primeira reunião, um texto inicial foi elaborado, baseado em evidências e opiniões dos especialistas do painel e, posteriormente, circulado entre os membros do painel, para revisão. Após a revisão, o documento foi enviado aos membros da SLAT para comentários e considerações e, finalmente, revisado e refinado pelos autores. As recomendações finais aqui apresentadas demonstram o estado da arte no manejo do câncer diferenciado da tireoide aplicadas aos países latino-americanos.Arq Bras Endocrinol Metab. 2009;53(7):884-97.

Descritores

Carcinoma da tireoide; ultrassonografia da tireoide; radioiodoterapia; tiroglobulina; consensus

\section{INTRODUCTION}

$\mathrm{T}$ he risk of malignancy in a thyroid nodule varies between $5 \%$ and $10 \%$ in iodine sufficient countries, and the amount of iodine supplemented in table salt influences on the morphology of the malignant tumor types (1).

Programs of table salt iodination in many Latin American countries have produced important variations in 
iodine intake over the past few decades, and the impact of these changes on the behavior of thyroid nodules and cancer is still largely unknown (2). The popularization of ultrasonography (US) and the simplicity of the technique to serve as guidance for aspiration of nodules have contributed to the apparent increase in incidence of differentiated thyroid carcinoma, as well as modified the clinical presentation of the cases diagnosed in Latin America and all over the world $(1,3)$.

New imaging technologies - especially US - have improved the sensitivity for detection of thyroid cancer, which is now often found incidentally on imaging studies performed for other indications. This has led to the identification of many patients with microscopic papillary thyroid cancers - mostly of no clinical significance (4).

New and refined surveillance approaches for patients with established diagnosis of thyroid cancer show that many patients who would be previously considered cured have, in fact, minimal residual disease.

Differentiated thyroid carcinoma (papillary and follicular) shows a wide spectrum of pathological subtypes according to the World Health Organization (WHO) system (5). Familial differentiated thyroid carcinoma may occur as site-specific tumors or as part of a hereditary tumor syndrome (for example: familial adenomatous polyposis, Cowden disease etc.). These are usually multicentric and occur mainly in young patients (6).

Although most patients with differentiated thyroid cancer have a favorable outcome, some are presenting with an aggressive form of the disease and a poor prognosis. Physicians in care of patients with thyroid carcinoma now have to grapple with a new array of issues that affect directly the decisions made in daily practice. A series of guidelines and consensus have been recently published; however, they are not always appropriate to different settings or countries.

Although the Argentinean and Brazilian endocrine societies have already published local guidelines for the follow-up and treatment of differentiated thyroid cancer $(7,8)$, the rest of the Latin American countries have not. The idea of the Latin American Thyroid Society (LATS) was to generate common recommendations, according to the different economic and social actualities of the integrating Latin American countries.

\section{MATERIALS AND METHODS}

A set of recommendations for evaluation and management of patients with differentiated thyroid cancer has been developed by 13 members of the LATS. This panel was composed by individuals involved in research and management of thyroid nodules and cancer from distinct reference medical centers in Latin America to reflect different practice patterns.

A first questionnaire assessing the most important issues on the subject (Table 1) was firstly sent to all panel members. The first meeting of the taskforce was held on August, 24 $4^{\text {th }}$ 2007, in Buenos Aires, Argentina. Prior to the meeting, the panel undertook a literature review by searching MedLine database. The search was classified by relevance according to:

1. randomized trials;

2. meta analysis;

3. clinical case series.

After the first meeting, a draft was developed. This preliminary text was analyzed by the entire panel of experts, and a draft document, based on the bibliographic search and expert opinion of the panel's participants, as well as on previously published information, was elaborated and circulated among panel members for further revision. This document was subsequently sent to some LATS members, for comments and discussion.

A second meeting was held in Rio de Janeiro, Brazil, on December $7^{\text {th }} 2007$. The text was finally revised and refined in complete agreement by the 13 panel members.

The final text aimed to represent the state of the art on thyroid cancer management applied to Latin American countries.

\section{RESULTS}

\section{Preoperative staging}

A series of studies with large cohorts of patients have demonstrated that age is a significant prognostic determinant in differentiated thyroid cancer (9). Other important factors included in most prognostic classifications are gender, tumor size on US evaluation, cytology (aggressive variants of papillary carcinoma), and evidence of extra-thyroidal invasion (10). These factors should be taken into consideration in planning for surgery.

\section{US}

Before surgery, the lobe contralateral to the tumor and the cervical area should be carefully evaluated by US in search of contralateral disease and suspicious lymph nodes at levels II, III, IV, V, and VI. It is noteworthy that 
Table 1. Questions pertaining differentiated thyroid cancer treatment and follow-up sent to the 13 panel members

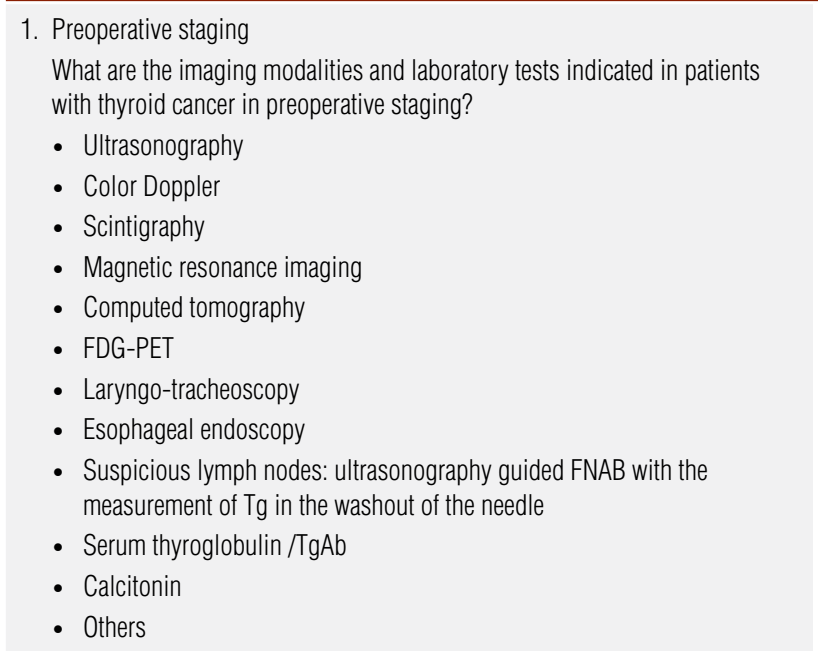

\section{Surgical treatment}

What is the appropriate primary surgical treatment of patients with thyroid cancer?
a) Surgical options for indeterminate cytology
- Thyroid lobectomy (and isthmectomy?)
- Completion thyroidectomy after lobectomy?
- Near-total or total thyroidectomy

b) Surgical options for malignant cytology (low-risk and high-risk patients)

- Thyroid lobectomy (and isthmectomy?)

- Completion thyroidectomy after lobectomy?

- Near-total or total thyroidectomy

c) Lymph nodes dissection

- Central compartment (Level VI) neck dissection

- Lateral compartment (Level II-IV) neck dissection. Affected side/both sides

- Posterior triangle (Level V) neck dissection

d) Surgical complications

- Laryngeal nerve palsy (laryngoscopy?)

- Hypocalcemia (Ionized calcium/PTH?)

3. Postoperative staging

Which should be the postoperative systems used?

4. Postoperative radiodine administration

When is the postoperative radiodine administration indicated?

Should urinary iodine excretion be measured before the radioiodine administration?

Is a low iodine diet necessary before remnant ablation?

Should pretreatment diagnostic scan be performed before remnant ablation? Is there a reduction in uptake of the ${ }^{131}$ I therapy dose induced by a pretreatment diagnostic dose?

What is the accuracy of low-dose ${ }^{131}$ s scan and post-treatment whole-body scan? What should be the activity of ${ }^{131}$ I used for remnant ablation after thyroxine withdrawal or recombinant human TSH stimulation?

Can rhTSH be used for remnant ablation in your country?

Should $\mathrm{Tg}$ be measured before the radiodiodine administration?

Is a post-therapy scan necessary after remnant ablation?

the size of the tumor may be underestimated when measured by US evaluation. This is particularly important in nodules measuring less than $1 \mathrm{~cm}$, in which partial
5. TSH-suppressive therapy

What is the appropriate degree of TSH suppression?

How long is TSH suppressive therapy mandatory?

When the suppression therapy must be avoided?

6. Follow-up protocol soon after initial therapy (surgery and radioiodine ablation)

- TSH-suppressive therapy. What is the appropriate degree of TSH suppression?

- When and what are laboratory tests indicated?

- TSH-stimulated serum thyroglobulin (levothyroxine withdrawal or rhTSH stimulation) and TgAb

- TSH-suppressed serum thyroglobulin and TgAb

- Management of thyroglobulin positive and imaging modalities negative patients

- When and what are imaging modalities indicated?

- Cervical ultrasonography

- Whole-body radioiodine scan

- Bone scintigraphy

- Computed tomography

- Magnetic resonance imaging

- FDG-PET

7. Long-term follow-up protocol

- TSH-suppressive therapy. What is the appropriate degree of TSH suppression?

- When and what are laboratory tests indicated?

- TSH-stimulated serum thyroglobulin (levothyroxine withdrawal or rhTSH stimulation) and TgAb

- TSH-suppressed serum thyroglobulin and TgAb

- When and what are imaging modalities indicated?

- Cervical ultrasonography

- Whole-body radioiodine scan

- Bone scintigraphy

- Computed tomography

- Magnetic resonance imaging

- FDG-PET

8. Flowchart or algorithm for long-term follow-up after initial treatment (surgery and radioiodine ablation)

9. Management of patients with recurrent or metastatic disease

- What is the most appropriate management of patients with local and regional recurrence?

- Surgery

- ${ }^{131}$ therapy

- Percutaneous ethanol injection

- Follow-up

- What is the most appropriate management of patients with distant metastases?

- Lung metastases

- Bone metastases

- Brain metastases

- Use of lithium in 131 l therapy

- What is the role of external beam radiotherapy?

- What is the role of chemotherapy?

thyroidectomy might be considered (9). Routine use of other imaging techniques, such as computed tomography $(\mathrm{CT})$, magnetic resonance (MRI), positron emis- 
sion tomography (PET) scan are not recommended before surgery, but may be useful in selected patients with aggressive cancers presenting with local extension or distant metastases.

\section{Laboratory tests}

Routine measurement of serum $\mathrm{Tg}$ levels before surgery is not recommended. Many studies have suggested the determination of preoperative serum calcitonin levels for detection of medullary thyroid cancer, but the cost-effectiveness of this approach is still unclear (11). Preoperative calcitonin may be measured when follicular cell or Hürthle cell neoplasia is suspected on FNAB, since medullary carcinoma with oncocytic features and with neoplastic follicular cell component may present that way (11).

The panel recommends the ultrasonographic neck evaluation previous to surgery but oppose to the measurement of thyroglobulin as a prognostic or diagnostic study before surgery.

\section{Surgical treatment}

The panel discussed very carefully this topic: a less aggressive surgical treatment (such as lobectomy plus isthmectomy, for example) is proposed by some, for low-risk patients with the argument that this approach may help preserve thyroid function and spare some patients from lifelong thyroid hormone replacement. However, L-T4 therapy is required in $50 \%$ of the patients immediately after lobectomy (12). In a majority of these patients, $\mathrm{L}-\mathrm{T}_{4}$ is ultimately required lifelong. Also, recurrence rates for patients with papillary carcinoma treated with lobectomy plus isthmectomy are higher than for those undergoing total thyroidectomy according to some (13) - but not all (14) - studies. There are a surprisingly high number of patients with papillary microcarcinomas $(\leq 1 \mathrm{~cm})$ with bilateral or multifocal disease, indicating that, even when these tumors are small in size, there is risk of leaving behind residual tumor in the contralateral lobe after hemithyroidectomy. Besides, performing total thyroidectomy at the time of diagnosis prevents the need for an additional surgical procedure in case of contralateral disease developed in the future. Patients with small $(<2 \mathrm{~cm})$ single nodules located far from the gland capsule and with no signs of extension are considered low risk for progression and, sometimes, referred for partial thyroidectomy. However, the prevalence of recurrence in these patients is not negligible $(15,16)$.
Taking into consideration the current lack of reliable markers of tumor progression and the fact that papillary microcarcinomas may occasionally be multifocal, invade the thyroid capsule, or present with lymph node or distant metastases (16), the panel recommends total thyroidectomy for differentiated thyroid carcinomas independent of size.

Although some patients may be over-treated by this approach, the panel considers that total thyroidectomy allows an adequate follow-up by permitting reliable $\mathrm{Tg}$ measurements.

There is an increased risk of hypoparathyroidism and recurrent laryngeal nerve injury following total thyroidectomy. In specialized centers, however, the occurrence of these complications is low and reported to be around 6\% for hypoparathyroidism (usually manifesting with transient hypocalcemia) and less than $1 \%$ for recurrent laryngeal injury.

Patients with indeterminate cytology on FNAB should be followed up and surgery should be indicated only in patients with risk factors (neck irradiation, familial papillary thyroid cancer) or in case of nodule enlargement. In these situations, lobectomy plus isthmectom is recommended, whereas total thyroidectomy is indicated for those with suspicious or malignant thyroid carcinoma.

There may be some situations when total thyroidectomy might not be performed, due to the low adherence of the patient to the follow-up. These circumstances are very characteristics of some specific regions of Latin America and they could happen in patients who live far away from the hospital and who are probably supposed not to return for the follow-up. In situations like this, that are usually seen in the inner cities of some Latin American countries, it could be preferable to perform a lobectomy, considering that some of these patients are probably not taking levothyroxine and the quality of life might be seriously affected with the chronic hypothyroid state.

If a unifocal microcarcinoma (in a very low-risk patient, for example) is diagnosed after a lobectomy made due to a diagnosis of a benign thyroid disorder, the completion thyroidectomy may be avoided.

Regarding surgical treatment, the panel recommends total thyroidectomy when a prospective diagnosis of thyroid cancer is performed, whatever the tumor size is. Lobectomy might be an option when a retrospective diagnosis of a microcarcinoma is made or when the cultural characteristic of the diagnosed patient might 
interfere with the subsequent controls in the long-term follow-up.

\section{Selective neck dissection for thyroid cancer}

The procedure of choice for thyroid cancer is selective neck dissection (SND), most often indicated with or without dissection of other neck levels. This procedure refers to the removal of lymph nodes within the central compartment of the neck, including the paratracheal, precricoid (Delphian), and perithyroidal lymph nodes, as well as the nodes located along the recurrent laryngeal nerves. This procedure is also known as the anterior neck dissection or the central compartment neck dissection. In the presence of metastases extending below the level of the suprasternal notch, dissection of the superior mediastinal nodes may be indicated; in this case, the procedure is designated SND (level VII, superior mediastinal nodes). In case of thyroid cancer with evidence of lateral nodal metastases, the procedure of choice should include the jugular nodes as well as the posterior triangle nodes and would be designated SND (II-V, VI) (7).

Central compartment neck dissection should be routinely considered only for those patients with $\mathrm{T} 3$ or T4 (TNM status) and is not warranted in all patients.

However, routine evaluation of the paratracheal area is recommended during surgery, in order to check for any evidence of suspicious lymph nodes. If suspicion is raised about a paratracheal area lymph node, a frozen section may be obtained and appropriate paratracheal clearance is recommended based on the pathological finding. Paratracheal clearance should include removal of levels VI and VII lymph nodes, if clinically apparent. Level VI lymph nodes include paratracheal nodes, while level VII includes superior mediastinal nodes, which are more concerning in patients with obvious metastatic disease at level VI. If at the time of surgery there is obvious metastatic disease in the jugular chain or lateral neck, modified neck dissection with removal of the lymph nodes at levels II, III, IV, and V is generally recommended. Modified neck dissection for thyroid carcinoma preserves all the important structures, such as the sternomastoid muscle, internal jugular vein, and accessory nerve, along with the submandibular salivary gland $(17,18)$.

Even though modified neck dissection is a reliable and safe surgical procedure for metastatic thyroid carcinoma, consideration must be given to certain complications, including high incidence of temporary and permanent hypoparathyroidism, recurrent laryngeal nerve injury, accessory nerve weakness leading to shoulder disability, chyle leak, bleeding and hematoma, Horner's syndrome, and injury to the brachial plexus or hypoglossal nerve (18). The consideration for neck dissection is evidently based on the surgeon experience in this procedure.

Patients undergoing neck dissection should be observed carefully in the postoperative period for serum calcium levels and symptoms of hypocalcemia, such as carpopedal spasm or tetany. These patients should be treated and maintained on calcium and vitamin $\mathrm{D}$ supplementation until serum calcium returns to normal levels, which may take up to two to three months.

At the time of surgery, if any portion of the parathyroid gland is identified as devascularized, parathyroid autotransplantation should be performed, preferably in the sternomastoid muscle or in the strap muscles. Prior to autotransplantation, it is important to reserve a small piece for frozen section analysis to confirm that the autotransplanted tissue is, in fact, a parathyroid gland, and not a lymph node or metastatic thyroid carcinoma.

SND is indicated in patients with diagnosed metastatic lymph nodes. The panel does not recommend the routine central neck dissection in all patients with diagnosis of papillary thyroid cancer; however, it is deserved for any patient with a T3 or T4 (TNM status).

\section{Postoperative staging}

The American Joint Committee on Cancer/International Union against Cancer (AJCC/UICC) TNM staging system $\left(6^{\text {th }}\right.$ edition $)$ should be used for assessment of patients with differentiated thyroid cancer on diagnosis and on every follow-up visit.

\section{Risk stratification}

The TNM system allows good stratification of the risk of death, but is weak in the prognostication of the recurrence risk (19). However, the following classification takes into consideration other variables that allow a reliable evaluation of the risk of disease persistence/ recurrence.

Clinical and pathological risk stratification following initial treatment might be included in the following categories:

- very low risk: patients with unifocal microcarcinoma and no extension beyond the thyroid capsule $(\mathrm{Tl} \leq \mathrm{lcm})$ and no local or distant metastases N0M0; 
- low risk: patients with uni- or multifocal tumors (T1 > $1 \mathrm{~cm}$, multifocal $\mathrm{Tl}$ or T2), no local or distant metastases (N0M0), in which all macroscopic tumor has been eliminated, no tumor invasion of locoregional tissues or structures, no vascular invasion, no ${ }^{131}$ I uptake outside the thyroid bed on the first post-treatment whole body scanning (WBS) scan, and with non-aggressive histological features such as tall cell, insular and columnar cell carcinomas;

- high risk: patients $>45$ years of age with large tumors (T3 and T4) or any T with lymph node/ regional metastases $(\mathrm{Nl})$, residual cancer after surgery (neck, distant sites, or both) or persistent disease, tumor extension beyond the thyroid capsule, distant metastases (Ml) in any age, or aggressive tumor histology (for example, tall cell, columnar cell or insular types).

\section{Postoperative radioiodine administration}

Effective thyroid ablation with radioiodine requires adequate stimulation by TSH. Remnant ablation can be achieved with the same effectiveness either by administration of recombinant human TSH or by thyroid hormone withdrawal. Radioablation is performed after thyroidectomy to destroy normal thyroid tissue that may have been left behind and increase the sensibility and specificity of Tg measurement. Many studies have shown that patients who undergo post-surgical radioablation of thyroid remnants have decreased disease recurrence rates compared with those who do not receive ablation $(20,21)$. Others, however, have concluded that, in low-risk patients, the incremental benefit of remnant ablation is unclear (22). Patients with papillary microcarcinoma receive ablation, especially when multicentricity, lymph node metastases and vascular or capsular invasion are encountered (23).

The panel recommends radioablation of thyroid remnants in all patients with high-risk thyroid cancer following total thyroidectomy. The procedure could be performed in low-risk patients and it is not mandatory in patients categorized as very low risk.

A low-iodine diet should be instituted 15 days before ${ }^{131} \mathrm{I}$ therapy and continued for two days after that. A daily iodine intake of about $50 \mu \mathrm{g}$ increases thyroidal ${ }^{131}$ I uptake and can potentially double the radiation per $100 \mathrm{mCi}$ of ${ }^{131} \mathrm{I}$ administered. The diet can be rather tedious, but an iodine intake limited to $50 \mu \mathrm{g}$ a day can be achieved by restricting use of iodized salt, dairy pro- ducts, eggs, and seafood (24). Although not routinely required, measurement of urinary iodine excretion may be useful in identifying patients in whom radioiodine should not be administered due to persistently high body iodine levels.

A diagnostic scan before radioiodine thyroid ablation is not usually indicated, but might be considered on special circumstances. For example, for assessment of the extent of the thyroidectomy in which large thyroid remnants may have remained and further surgery is required. It has been shown that diagnostic radioiodine doses may induce thyroid "stunning". This occurs most prominently with higher doses $(>3 \mathrm{mCi})$ of ${ }^{131} \mathrm{I}(25,26)$ and with increasing time between the diagnostic and the therapeutic ${ }^{131} \mathrm{I}$ administration (26). Stunning is usually not visually appreciated with ${ }^{123} \mathrm{I}$ or ${ }^{131}$ I doses below $3 \mathrm{mCi}$.

The usefulness of a pre-ablation radioiodine whole body scan is controversial.

Some of the members of the panel consider that a radioiodine dose around $100 \mu \mathrm{Ci}{ }^{131} \mathrm{I}$ could be administered only to perform a thyroid scintigraphy to show the extent of the surgery in selected cases, while others accept radioiodine doses up to $3 \mathrm{mCi}{ }^{131} \mathrm{I}$ to make a whole body scan before ablation.

Radioablation of thyroid remnants after thyroid hormone withdrawal can be accomplished in most instances by a single ${ }^{131} \mathrm{I}$ dose of $30 \mathrm{mCi}$, which delivers to the patient about 10 whole body rads $(27,28)$. A dose of $100 \mathrm{mCi}^{131} \mathrm{I}$ is more certain to provide ablation with a single administration than smaller doses, at the expense, however, of higher radiation exposure to the patient $(29,30)$.

Radioiodine doses in the range of 90 to $100 \mathrm{mCi}^{131} \mathrm{I}$ are recommended when rhTSH is administered as an adjuvant before ablation $(31,32)$. However, recent publications have shown that $50 \mathrm{mCi}^{131} \mathrm{I}$ is equally effective to $100 \mathrm{mCi}{ }^{131} \mathrm{I}$ for thyroid remnant ablation following rhTSH, with no interruption in ${\mathrm{L}-\mathrm{T}_{4}}_{4}$ administration $(33,34)$. The use of rhTSH for ablation has shown to produce lesser exposure of radioiodine to the bone marrow and lowered toxicity related to the radioiodine dose than when administered after withdrawal $(35,36)$. Short term recurrence of disease seems to be the same when a patient is prepared after thyroid hormone withdrawal than when performed after rhTSH (32).

In Latin America, the use of rhTSH has been approved as an adjuvant for thyroid remnant ablation in Argentina, Brazil, Chile, Colombia, Mexico, Peru and Uruguay. 
A post-therapeutic (WB) should be performed within five to eight days after radioiodine ablation of thyroid remnants to detect additional uptaking foci, that may not have been detected with the diagnostic radioiodine dose (37).

The panel recommends the use of radioiodine doses higher than $30 \mathrm{mCi}^{131} \mathrm{I}$ when performed after withdrawal. If rhTSH is used, a radioiodine dose higher than $50 \mathrm{mCi}$ ${ }^{131}$ I seems to be enough to destroy the thyroid remnants.

\section{TSH-suppressive therapy}

TSH-suppressive therapy is associated with increased survival (38).

In patients with low-risk thyroid cancer and without evidence of recurrence or metastases, serum TSH levels may be maintained between 0.4 and $1.0 \mathrm{mU} / \mathrm{L}$. Patients with high risk should receive TSH suppression while they keep the high-risk status; aimed serum TSH values in these patients should be below $0.1 \mathrm{mU} / \mathrm{L}$. If a high-risk patient is defined as free of disease, a decrease in $\mathrm{L}-\mathrm{T}_{4}$ dose is recommended after three to five years of follow-up. In very low-risk patients, it is not necessary to suppress TSH levels. The thyroid hormone therapy can be administered in order to keep a TSH level into the normal range.

Contraindications for suppressive therapy are: atrial fibrillation, severe osteoporosis, and ischemic cardiovascular disease (39).

\section{Immediate follow-up after surgery and radioiodine ablation}

The first serum stimulated $\mathrm{Tg}$ determination after hypothyroidism post-surgery is a good prognosticator. An initial $\mathrm{Tg}$ value above $70 \mathrm{ng} / \mathrm{mL}$ has a positive predictive value of $90 \%$ for detection of metastases (40). Pre-ablative Tg levels have also been shown to be an independent prognostic indicator for disease-free remission by another study, in which levels above $27.5 \mathrm{ng} /$ $\mathrm{mL}$ were associated with a positive predictive value of 98\% (41). The ideal timing for serum Tg measurement is immediately before ${ }^{131} \mathrm{I}$ administration, if patients undergo $\mathrm{L}_{-} \mathrm{T}_{4}$ withdrawal. The $\mathrm{Tg}$ measurement after rhTSH may not reflect only the thyroid cells stimulation, but also the thyroid cellular destruction, considering that it must be measured after the radioiodine dose administration (fifth day after the first injection).

Serum Tg should be measured with a sensitive immunometric assay (functional sensitivity $<1.0 \mathrm{ng} / \mathrm{mL}$ ) standardized on the European reference standard (CRM 457 ). The emergence of new second generation $\mathrm{Tg}$ assays or molecular markers in the future might allow a more adequate follow-up of patients with residual thyroid tissue.

The presence of circulating thyroglobulin antibodies $(\mathrm{Tg}-\mathrm{Ab})$ may interfere with immunometric assays and yield falsely lower Tg determinations. Approximately $25 \%$ of the thyroid cancer patients and $10 \%$ of the general population have $\mathrm{Tg}-\mathrm{Ab}$, and their presence must be ruled out by direct measurement of $\mathrm{Tg}-\mathrm{Ab}$, instead of using the $\mathrm{Tg}$ recovery test. Serial serum $\mathrm{Tg}$ - $\mathrm{Ab}$ measurements may serve as an imprecise surrogate marker of residual normal thyroid tissue or tumor (42).

The panel recommends the assessment of serum $\mathrm{Tg}$ before ablation when it will be performed after thyroid hormone withdrawal. The moment when measuring serum $\mathrm{Tg}$ after ablation with rhTSH has not been addressed yet.

\section{TSH-stimulated serum thyroglobulin and $\mathrm{Tg}-\mathrm{Ab}$ measurement in short term follow-up}

In very low-risk and non-ablated patients, the risk of persistent or recurrent disease is small by definition, and TSH-stimulated serum $\mathrm{Tg}$ and $\mathrm{Tg}$ - $\mathrm{Ab}$ measurement is usually not necessary. Follow-up with serum $\mathrm{Tg}$ and $\mathrm{Tg}-\mathrm{Ab}$ determinations during $\mathrm{L}-\mathrm{T}_{4}$ treatment combined with neck US every 6 to 12 months is recommended for these patients.

In patients with low-risk thyroid carcinoma, serum $\mathrm{Tg}$ and $\mathrm{Tg}-\mathrm{Ab}$ measurement following $\mathrm{L}-\mathrm{T}_{4}$ withdrawal or rhTSH administration should be performed around 12 months after surgery. At this point, WBS is not mandatory $(43,44)$ (Figure 1).

A Tg cut-off level of $2 \mathrm{ng} / \mathrm{mL}$ after rhTSH stimulation is highly sensitive to identify patients with persistent tumor (45). Approximately $20 \%$ of patients who are clinically free of disease and have serum $\mathrm{Tg}$ levels below $\mathrm{l} \mathrm{ng} / \mathrm{mL}$ during $\mathrm{L}^{-} \mathrm{T}_{4}$ suppressive therapy will present levels above $2 \mathrm{ng} / \mathrm{mL}$ after rhTSH or thyroid hormone withdrawal (46); persistent tumor may be identified on imaging studies in about $1 / 3$ of these patients. In patients with small cervical lymph node metastases or less differentiated tumors, serum non-stimulated $\mathrm{Tg}$ measurements have lower sensitivity (47). The clinical significance of minimally detectable $\mathrm{Tg}$ levels is still unclear, especially when an increase is only detected after TSH stimulation. In any case, a rising (non-stimulated or stimulated) serum $\mathrm{Tg}$ may indicate a disease likely to become clinically apparent $(46,47)$. 


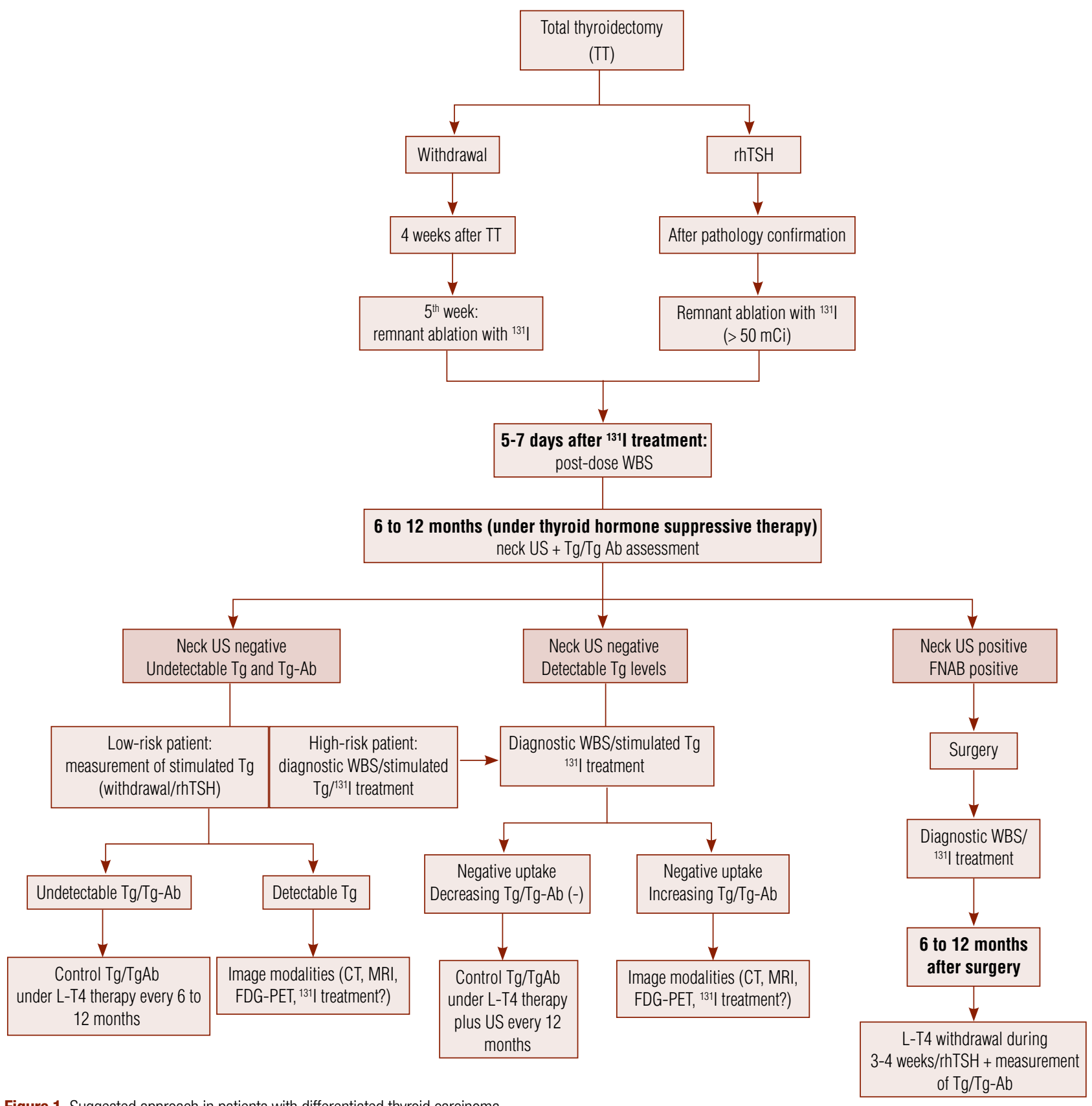

Figure 1. Suggested approach in patients with differentiated thyroid carcinoma.

It is noteworthy that results of serum $\mathrm{Tg}$ measurements performed on the same serum specimen differ among laboratories. Therefore, the Tg cut-off may differ slightly among medical centers and different laboratories. The frequency for subsequent stimulated testing is not clearly established for patients found to be free from the disease (47).

In patients with low-risk thyroid cancer, the panel recommends to measure a stimulated $\mathrm{Tg}$ level after one year of initial treatment. Diagnostic WBS is not necessary, at this point, in this group of patients.
Serum thyroglobulin and $\mathrm{Tg}-\mathrm{Ab}$ measurement during L-T4 therapy

Measurement of serum $\mathrm{Tg}$ and $\mathrm{Tg}-\mathrm{Ab}$ during TSH suppressive therapy should be performed between 6 to 12 months after surgery, based on each patient's risk.

\section{Cervical US}

Cervical US is highly sensitive in detecting cervical metastases in patients with differentiated thyroid cancer, especially when associated to a stimulated $\mathrm{Tg}$ level (48). 
It should be ideally performed at 6 and 12 months after surgery, and annually thereafter, depending on the patient's risk for recurrence and on Tg levels.

Neck US is an operator-dependent procedure, and a learning curve may improve individual performance. This procedure is more sensitive than neck palpation, has the ability to detect lymph nodes as small as 2 to $3 \mathrm{~mm}$ in diameter, and may be used routinely for assessing lymph node chains as well as evaluating the thyroid bed. Benign lymph node hyperplasia is frequent and a distinction should be made between hyperplasia and metastatic disease. Important US criteria suggesting malignancy include cystic appearance, hyperechoic punctuations (microcalcifications), loss of hyperechoic hilum and peripheral vascularization (49).

For lymph nodes that present a short axis larger than $0.5 \mathrm{~cm}$ that persist over several months, the specificity of neck US may be improved by assessing the US characteristics of the lymph nodes and by performing US-FNAB for cytology and Tg measurement in the aspirate fluid. Lymph nodes with short axis equal or smaller than $0.5 \mathrm{~cm}$ should be carefully described and followed with periodical US monitoring.

US should be performed initially at 3 to 6 months after total thyroidectomy and, then, every 6 to 12 months, depending on the patient risk. If one low-risk or very low-risk patient is considered free from the disease after three to five years of follow-up, then, no more annual ultrasonographic control is needed.

\section{Indications for other imaging modalities}

\section{WBS}

An increase in TSH levels should be obtained before administration of ${ }^{131}$ I for diagnosis or therapeutic purpose. High TSH levels can be achieved after three to four weeks of thyroid hormone withdrawal. A TSH level higher than $30 \mathrm{mUI} / \mathrm{mL}$ is usually required $(50,5 \mathrm{l})$. Another option is the administration of $\operatorname{rhTSH}(0.9 \mathrm{mg}$ intramuscularly) for two consecutive days, followed by ${ }^{131}$ I on the third day. Serum Tg should be measured on the fifth day, when performed after rhTSH administration, and before radioiodine administration, when performed after withdrawal $(43,45,52)$.

Following administration of ${ }^{131} \mathrm{I}$ for ablation or therapy, WBS should be performed within five to seven days.

A practical approach for the follow-up of patients with differentiated thyroid cancer can be appreciated in figure 1 .

\section{Bone scintigraphy}

The panel does not recommend routine bone scintigraphy.

\section{Computed tomography}

Recommendations for CT include suspicion of lung, mediastinal, CNS and bone metastases.

\section{Magnetic resonance imaging}

MRI is useful in the diagnosis of mediastinal and central nervous system metastases.

\section{FDG-PET}

FDG-PET is recommended for patients with detectable non-stimulated or stimulated serum Tg levels (above $10 \mathrm{ng} / \mathrm{mL}$ ), but negative WBS, to help identifying metastatic lesions (53). Stimulation with endogenous TSH after ${\mathrm{L}-\mathrm{T}_{4}}_{4}$ withdrawal or rhTSH (54) and CT fusion may enhance the sensitivity and specificity of FDGPET scanning.

\section{Management of patients with elevated $\mathrm{Tg}$ and negative imaging tests}

Pulmonary metastases may occasionally be discovered on post-treatment WBS after administration of a large ${ }^{131} \mathrm{I}$ dose (55). In one study, about $6 \%$ of 283 patients with high serum $\mathrm{Tg}$ levels treated with $100 \mathrm{mCi}$ ${ }^{131}$ I had distant metastases detected on post-treatment WBS that were not detected on a $2 \mathrm{mCi}$ pre-treatment $\operatorname{scan}(56)$.

The panel suggests that patients with negative imaging and increasing non-stimulated or stimulated $\mathrm{Tg}$ levels, higher than $10 \mathrm{ng} / \mathrm{mL}$, might be treated with a higher radioiodine dose $\left(>100 \mathrm{mCi}^{131} \mathrm{I}\right)$ to increase radioiodine uptake of eventual metastases. If no uptake is visible after high radioiodine dose, no additional radioiodine should be administered.

\section{Low functional sensitivity $\mathrm{Tg}$ assays}

Low functional sensitivity $\mathrm{Tg}$ assays have a higher sensitivity, but at the expense of a lower specificity $(57,58)$. The future emergence of second generation $\mathrm{Tg}$ assays will probably reduce the need of TSH-stimulated $\mathrm{Tg}$ measurement in some patients (59).

The panel does not recommend the routine use of low functional sensitivity $\mathrm{Tg}$ assays until more evidence is published regarding its efficacy. 


\section{Management of patients with positive $\mathrm{Tg}-\mathrm{Ab}$}

In patients with $\mathrm{Tg}$ - $\mathrm{Ab}$ positivity, undetectable serum $\mathrm{Tg}$ levels should not be interpreted as evidence of remission. These patients must be monitored with periodical neck US and diagnostic ${ }^{131}$ I WBS instead of serum $\mathrm{Tg}$ determinations. If there is suspicion of distant disease, patients should also undergo evaluation with other imaging techniques such as CT, MRI, or FDGPET. The disappearance of $\mathrm{Tg}-\mathrm{Ab}$ during follow-up may itself be considered evidence of remission in these patients.

\section{Management of patients with recurrent or metastatic disease}

\section{Surgery}

When local recurrences are detected, a complete ipsilateral dissection of the compartments with persistent/ recurrent disease should be performed, sparing vital structures whenever possible (for example, modified levels II-V neck dissection sparing the spinal accessory nerve, the internal jugular vein, and the sternocleidomastoid muscle). Neck dissection of the VI and VII compartments should be carried out in case it was not performed during total thyroidectomy.

\section{${ }^{131}$ / therapy}

Administration of fixed doses of ${ }^{131} \mathrm{I}$ to patients with metastatic disease is a simpler, but sometimes not safer, approach compared with administration of calculated doses. The main disadvantage of fixed doses, however, is that some patients may receive insufficient ${ }^{131}$ I to adequately treat their tumors. However, the disadvantage with high fixed doses, especially in elderly people, can be the risk of exceeding the maximum tolerated radiation dose.

In general, lymph node metastases too small to be excised surgically should be treated with doses ranging from 150 to $175 \mathrm{mCi}$. Patients with cancer growth through the thyroid capsule should be managed with doses ranging from 150 to $200 \mathrm{mCi}$, and those with distant metastases with 200 to $300 \mathrm{mCi}$, which is unlikely to cause severe radiation sickness or serious damage to critical structures. Lung metastases are generally treated with doses between 200 to $250 \mathrm{mCi}^{131} \mathrm{I}$. Again, this radioiodine doses can be deleterious, above all in the elderly. Caution is recommended when radioiodine doses are empirically administered in older patients.

\section{${ }^{131}$ I treatment of metastases after rhTSH}

The panel recommends that thyroid hormone withdrawal precede the treatment of metastases with ${ }^{131} \mathrm{I}$. However, in elderly patients or in those with contraindication for thyroid hormone withdrawal, good results have been shown with ${ }^{131} \mathrm{I}$ therapy preceded by rhTSH stimulation $(60,61)$. The use of prophylactic glucocorticoids is recommended when therapeutic ${ }^{131} \mathrm{I}$ is administered in patients with metastatic disease after rhTSH to prevent tumor enlargement $(61,62)$.

The ideal approach for patients with metastatic lesions is real dosimetry. Recent studies using PET scans (with ${ }^{124} \mathrm{I}$ ) have shown that this approach allows calculation of both the volume of the metastatic lesions and the radioiodine uptake (63). Therapeutic options for patients with locally advanced disease not able to receive surgical treatment and/or distant metastases are rarely curative, but may be effective in reducing tumor size and improving quality of life.

\section{Follow-up in patients with metastatic disease}

In patients who develop metastatic disease that uptakes ${ }^{131}$ I, new doses of ${ }^{131}$ I should be administered until disease control, appearance of adverse events, or loss of radioiodine uptake.

\section{Lung metastases}

In case a single nodular metastasis is present in the lung, surgical excision is recommended, provided there is easy access. If multinodular or diffuse metastases are encountered, radioiodine should be the treatment of choice.

\section{Bone metastases}

Bone metastases should be treated with a combination of surgery when possible, administration of ${ }^{131} \mathrm{I}$, if uptake is present, and external beam radiotherapy either as a palliative treatment or to help control pain.

\section{Brain metastases}

Depending on the accessibility, surgery is recommended in this case, followed by radioiodine administration. Special care should be taken with occurrence of hemorrhagic stroke after radioiodine; in this case, glucocorticoids should be used preventively. If the tumor is unresectable and non-iodine avid, external beam radiotherapy should be considered to provide palliation. 
Glucocorticoids is recommended when therapeutic ${ }^{131} \mathrm{I}$ is administered in patients with metastatic brain disease to prevent tumor enlargement due to swelling.

\section{Use of lithium with ${ }^{131}$ | therapy}

Lithium may be a useful adjuvant for ${ }^{131} \mathrm{I}$ therapy of metastatic disease, increasing both the accumulation and the retention of the isotope in the lesion. Given at a dose of $300 \mathrm{mg}(10 \mathrm{mg} / \mathrm{kg})$ one to three times daily and starting about a week before ${ }^{131} \mathrm{I}$ therapy, lithium increases uptake in metastatic lesions while only slightly increasing it in normal thyroid tissue. The drug enhances ${ }^{131}$ I retention probably as a result of its inhibitory effect on iodine release from both normal and neoplastic follicular cells (64).

Lithium maximizes the irradiation of tumors in which the biologic half-life of iodine is less than six days without increasing irradiation to other organs. The largest increase in tumor irradiation occurs in lesions with a biological half-life of less than three days. Retention of ${ }^{131}$ I during lithium therapy increases $50 \%$ in tumors and $90 \%$ in thyroid remnants, the net effect being more than a 2 -fold average increase in the irradiation dose to metastatic tumor. Serum lithium levels should be measured daily and maintained between 0.8 and 1.2 $\mathrm{nmol} / \mathrm{L}$. The drug may be continued for five to seven days after therapy, and, since lithium levels cannot be measured immediately after ${ }^{131}$ I therapy, one must carefully avoid lithium toxicity during this time (64).

The panel considers that lithium might be used in selected cases to increase the effect of the radiodiodine in selected patients with metastatic disease.

\section{External beam radiotherapy}

External beam radiotherapy should be used as palliative therapy or for pain control. It may be recommended as initial treatment for recurrent or unresectable tumors, or for tumors with local invasion, presumed to have macro- or microscopic residual disease that do not concentrate ${ }^{131}$ I. External beam radiotherapy may also be indicated in patients with bone or brain metastases.

\section{Other considerations}

For patients with locally advanced disease, unresectable cancer and/or distant metastases in whom all therapeutic options have failed and disease progresses, there is the option of systemic chemotherapy with doxorubicin as a single agent or combined with cisplatin (65).
In general, the response rates are low, short lasting, and associated with a high degree of toxicity.

\section{Targeted therapy in advanced thyroid cancer}

Targeted therapies are generally cytostatic and not cytotoxic, which may pose a problem, since thyroid cancer requires life-long therapy. This may be satisfactory if the drug has low toxicity and is well tolerated. However, there is usually a high risk that "resting" neoplastic cells may develop compensatory pathways, often by acquiring other mutations leading to disease progression.

Gefitinib is a small molecule inhibitor of EGFR tyrosine kinase. Therapy with oral dose of $250 \mathrm{mg}$ once daily achieves reduction in tumor volume. However, in a phase II study, it did not meet criteria for partial response rate in $32 \%$ of the patients and stabilization of the disease in $46 \%, 24 \%$, and $12 \%$ of the patients after 3 , 6 , and 12 months of treatment, respectively (66).

Motesanib diphosphate (AMG 706) is a novel oral inhibitor of vascular endothelial growth factor (VEGF) receptors. In a phase II trial in patients with advanced thyroid cancer, out of 93 patients with follicular cellderived thyroid cancer treated with $125 \mathrm{mg}$ of motesanib diphosphate, $14 \%$ experienced a complete or partial response and $67 \%$ had stable disease (67).

Sorafenib is a kinase inhibitor, including Raf kinase, VEGF receptor, platelet-derived growth factor receptor and RET tyrosine kinases. In a phase II trial in 30 patients with advanced thyroid cancer, partial remission was achieved in 7 (23\%) and stable disease in $16(53 \%)$ patients (68).

Others kinase inhibitors that have been used in phase II clinical trials with partial response or stable disease include axitinib (VEGFR) and sunitinib (RET, VEGFR and PDGFR) (69).

Thalidomide is an antiangiogenic agent and has been used for therapy of radioiodine-unresponsive and rapidly progressive thyroid carcinomas with partial response in $18 \%$ and stable disease in $32 \%$ of the patients. Daily dose starts at $200 \mathrm{mg}$ and is increased over six weeks to $800 \mathrm{mg}$ or to the maximum tolerated dose (70). The kinase inhibitors and other agents that target vascularity appear to have activity in thyroid cancer that results in partial remission in some patients and stable disease in a large group of patients (approximately $50 \%$ ). These agents appear unlikely to cure patients with progressive metastatic disease. Also, treatmentrelated adverse events are common with these drugs 
and can reduce quality of life. Potentially severe side effects include diarrhea, hypertension, fatigue, weight loss, and hand-foot syndrome.

The panel recommends considering the enrolling of patients with no other therapeutic option in any clinical trials available.

\section{Thyroid cancer in children}

It should be noted that children usually have larger tumors and a higher incidence of lymph node metastases at presentation. According to the large series from the Cancer Registry of England and Wales the proportion of childhood thyroid cancer was: papillary carcinoma (68\%), follicular carcinoma (11\%), medullary carcinoma (17\%) and others (4\%). Cervical lymph node involvement was present in the majority of children affected with thyroid cancer (71).

Most authors recommend total or near-total thyroidectomy followed by ablation with ${ }^{131} \mathrm{I}$ and thyroid hormone suppressive therapy in children with differentiated thyroid carcinoma. When metastases are present, selective lymph node dissection is indicated.

Although rhTSH is not approved to be used in this setting, in Latin America we had one of the first experiences of its use (72).

\section{Differentiated thyroid cancer during pregnancy}

Pregnant women who are diagnosed with thyroid cancer share similar physical findings, pathological tumor features and outcome as those who were not pregnant (73). Treatment in this group of patients is also similar to that in non-pregnant women. In case of differentiated thyroid cancer, the prognosis among pregnant and non-pregnant women of the same age is equal. The use of ${ }^{131}$ I for diagnostic or therapeutic purposes after delivery is safe, providing the patient is not breastfeeding.

The panel recommends that the diagnosis and treatment of thyroid cancer that occurs during pregnancy be delayed until after delivery in most patients.

Acknowledgments: We gratefully acknowledge the contributions of Cristiane Almeida, Denise Wittmann, Geraldo Medeiros-Neto, Hector Perinetti, Liliana Bergoglio, Luiz Kowalski, Marcos Tavares, Marilia Marone, Milena Braga-Basaria, Nilton Hanaoka, Nilton Herter, Rui Maciel, Sergio Toledo, and Suemi Marui.

Disclosure: Sandro Corigliano works as Clinical Investigator for Takeda, GlaxoSmithKline, Merck Sharp Dohme, and Novartis; as Advisory Board for Sanofi-Aventis, and Merck Sharp Dohme; and as Local Speaker for GlaxoSmithKline, Merck Sharp Dohme, Sanofi-Aventis, and Abbott. Fabian Pitoia works as a consultant and speaker bureau for Genzyme Corp. The others authors have no competing financial interests.

\section{REFERENCES}

1. Harach HR, Ceballos GA. Thyroid cancer, thyroiditis and dietary iodine: a review based on the Salta, Argentina model. Endocr Pathol. 2008;19(4):209-20.

2. Pretell EA, Delange F, Hostalek U, Corigliano S, Barreda L, Higa AM, et al. lodine nutrition improves in Latin America. Thyroid. 2004;14(8):595-604.

3. Davies L, Welch HG. Increasing incidence of thyroid cancer in the United States, 1973-2002. JAMA. 2006; 295(18):2164-7.

4. Harach HR, Franssila KO, Wasenius VM. Occult papillary carcinoma of the thyroid. A "normal" finding in Finland. A systematic autopsy study. Cancer. 1985;56(3):531-8.

5. Sobrinho-Simoes M, Asa SL, KrollTG, et al. Follicular carcinoma. In: DeLellis RA, Lloyd RV, Heitz PU, Eng C (editors). Pathology and genetics of tumours of endocrine organs. Lyon: WHO Classification of Tumours; 2004. p. 67-72.

6. Foulkees WD, Kloos RT, Harach HR, Li Volsi V. Familial non-medullary thyroid cancer. In: DeLelis RA, Lloyd RV, Heitz PU, Eng C (editors).WHO classification of tumors pathology and genetics of tumors of endocrine organs. Lyon:WHO; 2004. p. 257-61.

7. Gauna A, Gutiérrez S, Miras M, Niepomniszcze H, Parma R. Consenso argentino de carcinoma diferenciado de tiroides. Rev Arg Endocrinol Metab. 2006;43(3):131-6.

8. Maia AL, Ward LS, Carvalho GA, Graf H, Maciel RM, Maciel LM, et al. Thyroid nodules and differentiated thyroid cancer: Brazilian consensus. Arq Bras Endocrinol Metabol. 2007;51(5):867-93.

9. Hundahl SA, Fleming ID, Fremgen AM, Menck HR. A National Cancer Data Base report on 53,856 cases of thyroid carcinoma treated in the U.S., 1985-1995. Cancer. 1998;83(12):2638-48.

10. Deveci MS, Deveci G, LiVolsi VA, Gupta PK, Baloch ZW. Concordance between thyroid nodule sizes measured by ultrasound and gross pathology examination: effect on patient management. Diagn Cytopathol. 2007;35(9):579-83.

11. Mathias-Guiu X, DeLelis RA, Moley JF, et al. Medullary carcinoma. In: DeLellis RA, Lloyd RV, Heitz PU, Eng C (editors). Pathology and genetics of tumours of endocrine organs. Lyon: WHO Classification of Tumours; 2004. p. 86-91.

12. Farkas EA, King TA, Bolton JS, Fuhrman GM. A comparison of total thyroidectomy and lobectomy in the treatment of dominant thyroid nodules. Am Surg. 2002;68(8):678-82.

13. Hay ID, McConahey WM, Goellner JR. Managing patients with papillary thyroid carcinoma: insights gained from the Mayo Clinic's experience of treating 2,512 consecutive patients during 1940 through 2000. Trans Am Clin Climatol Assoc. 2002; 113:241-60.

14. Appetecchia M, Scarcello G, Pucci E, Procaccini A. Outcome after treatment of papillary thyroid microcarcinoma. J Exp Clin Cancer Res. 2002; 21(2):159-64.

15. Bonnin C, Trojani M, Corcuff JB, Bonichon F. Outcome of 111 thyroid papillary carcinomas. Retrospective study from 1953 to 1994. Experience of Bergonie Institute. Ann Endocrinol (Paris). 1997;58(4):318-25.

16. Satge D, Grob JC, Pusel J, Methlin G. [Thyroid microcarcinoma with a fatal outcome and 34 other unusually aggressive cases reported in the literature]. Arch Anat Cytol Pathol. 1990;38(4):143-51.

17. Robbins KT, Clayman G, Levine PA, Medina J, Sessions R, Shaha $A$, et al. Neck dissection classification update: revisions proposed by the American Head and Neck Society and the American Academy of Otolaryngology-Head and Neck Surgery. Arch Otolaryngol Head Neck Surg. 2002;128(7):751-8. 
18. Shaha AR. Complications of neck dissection for thyroid cancer. Ann Surg Oncol. 2008;15(2):397-9.

19. Loh KC, Greenspan FS, Gee L, Miller TR, Yeo PP. Pathological tumor-node-metastasis (pTNM) staging for papillary and follicular thyroid carcinomas: a retrospective analysis of 700 patients. J Clin Endocrinol Metab. 1997;82(11):3553-62.

20. Mazzaferri EL, Jhiang SM. Long-term impact of initial surgical and medical therapy on papillary and follicular thyroid cancer. Am J Med. 1994;97(5):418-28.

21. Samaan NA, Schultz PN, Hickey RC, Goepfert H, Haynie TP, Johnson DA, et al. The results of various modalities of treatment of well differentiated thyroid carcinomas: A retrospective review of 1599 patients. J Clin Endocrinol Metab. 1992;75(3):714-20.

22. Sawka AM, Thephamongkhol K, Brouwers M, Thabane L, Browman G, Gerstein HC. Clinical review 170: A systematic review and metaanalysis of the effectiveness of radioactive iodine remnant ablation for well-differentiated thyroid cancer. J Clin Endocrinol Metab. 2004;89(8):3668-76.

23. Pellegriti G, Scollo C, Lumera G, Regalbuto C, Vigneri R, Belfiore A. Clinical behavior and outcome of papillary thyroid cancers smaller than $1.5 \mathrm{~cm}$ in diameter: study of 299 cases. J Clin Endocrinol Metab. 2004;89(8):3713-20.

24. Lakshmanan M, Schaffer A, Robbins J, Reynolds J, Norton J. A simplified low iodine diet in I-131 scanning and therapy of thyroid cancer. Clin Nucl Med. 1988;13(12):866-8.

25. Park HM, Perkins OW, Edmondson JW, Schnute RB, Manatunga A. Influence of diagnostic radioiodines on the uptake of ablative dose of iodine-131. Thyroid. 1991;4(1):49-54.

26. Jeevanram RK, Shah DH, Sharma SM, Ganatra RD. Influence of initial large dose on subsequent uptake of therapeutic radioiodine in thyroid cancer patient. Int J Rad Appl Instrum B. 1986;13(3):277-9.

27. Rosario PW, Reis JS, Barroso AL, Rezende LL, Padrao EL, Fagundes TA. Efficacy of low and high ${ }^{131}$ I doses for thyroid remnant ablation in patients with differentiated thyroid carcinoma based on post-operative cervical uptake. Nucl Med Commun. 2004;25(11):1077-81.

28. Bal C, Padhy AK, Jana S, Pant GS, Basu AK. Prospective randomized clinical trial to evaluate the optimal dose of 131 I for remnant ablation in patients with differentiated thyroid carcinoma. Cancer. 1996;77(12):2574-80.

29. Johansen K, Woodhouse NJ, Odugbesan O. Comparison of 1073 $\mathrm{MBq}$ and $3700 \mathrm{MBq}$ iodine-131 in postoperative ablation of residual thyroid tissue in patients with differentiated thyroid cancer. J Nucl Med. 1991;32(2):252-4.

30. Ward LS. High-dose radioiodine outpatient therapy. Arq Bras Endocrinol Metabol. 2009;53(3):301-2.

31. Pacini F, Ladenson PW, Schlumberger M, Driedger A, Luster $M$, Kloos RT, et al. Radioiodine ablation of thyroid remnants after preparation with recombinant human thyrotropin in differentiated thyroid carcinoma: results of an international, randomized, controlled study. J Clin Endocrinol Metab. 2006;91(3):926-32.

32. Tuttle RM, Brokhin M, Omry G, Martorella AJ, Larson SM, Grewal $\mathrm{RK}$, et al. Recombinant human TSH-assisted radioactive iodine remnant ablation achieves short-term clinical recurrence rates similar to those of traditional thyroid hormone withdrawal. J Nucl Med. 2008;49(5):764-70.

33. Pilli T, Brianzoni E, Capoccetti F, Castagna MG, Fattori S, Poggiu A, et al. A comparison of $1850(50 \mathrm{mCi})$ and $3700 \mathrm{MBq}(100 \mathrm{mCi})$ 131-iodine administered doses for recombinant thyrotropin-stimulated postoperative thyroid remnant ablation in differentiated thyroid cancer. J Clin Endocrinol Metab. 2007;92(9):3542-6.

34. Chianelli M, Todino V, Graziano FM, Panunzi C, Pace D, Guglielmi $\mathrm{R}$, et al. Low-activity $(2.0 \mathrm{GBq} ; 54 \mathrm{mCi})$ radioiodine post-surgical remnant ablation in thyroid cancer: comparison between hormo- ne withdrawal and use of rhTSH in low-risk patients. Eur J Endocrinol. 2009;160(3):431-6.

35. Hänscheid $H$, Lassmann M, Luster M,Thomas SR, Pacini F, Ceccarelli $\mathrm{C}$, et al. lodine biokinetics and dosimetry in radioiodine therapy of thyroid cancer: procedures and results of a prospective international controlled study of ablation after rhTSH or hormone withdrawal. J Nucl Med. 2006;47(4):648-54.

36. Rosário PW, Borges MA, Purisch S. Preparation with recombinant human thyroid-stimulating hormone for thyroid remnant ablation with ${ }^{131} \mathrm{I}$ is associated with lowered radiotoxicity. J Nucl Med. 2008;49(11):1776-82.

37. Fatourechi V, Hay ID, Mullan BP, Wiseman GA, Eghbali-Fatourechi GZ, Thorson LM, et al. Are posttherapy radioiodine scans informative and do they influence subsequent therapy of patients with differentiated thyroid cancer? Thyroid. 2000;10(7):573-7.

38. Pujol P, Daures JP, Nsakala N, Baldet L, Bringer J, Jaffiol C. Degree of thyrotropin suppression as a prognostic determinant in differentiated thyroid cancer. J Clin Endocrinol Metab. 1996;81(12):4318-23.

39. Parle JV, Maisonneuve P, Sheppard MC, Boyle P, Franklyn JA. Prediction of all-cause and cardiovascular mortality in elderly people from one low serum thyrotropin result: a 10 -year cohort study. Lancet. 2001;358(9285):861-5.

40. Ronga G, Filesi M, Ventroni G, Vestri AR, Signore A. Value of the first serum thyroglobulin level after total thyroidectomy for the diagnosis of metastases from differentiated thyroid carcinoma. Eur J Nucl Med. 1999;26(11):1448-52.

41. Heemstra KA, LiuYY, Stokkel M, Kievit J, Corssmit E, Pereira AM, et al. Serum thyroglobulin concentrations predict disease-free remission and death in differentiated thyroid carcinoma. Clin Endocrinol (Oxf). 2007;66(1):58-64.

42. Spencer CA, Takeuchi M, Kazarosyan M, Wang CC, Guttler RB, Singer PA, et al. Serum thyroglobulin autoantibodies: prevalence, influence on serum thyroglobulin measurement, and prognostic significance in patients with differentiated thyroid carcinoma. $\mathrm{J}$ Clin Endocrinol Metab. 1998;83(4):1121-7.

43. Haugen BR, Ridgway EC, McLaughlin BA, McDermott MT. Clinical comparison of whole-body radioiodine scan and serum thyroglobulin after stimulation with recombinant human thyrotropin. Thyroid. 2002;12(1):37-43.

44. Cailleux AF, Baudin E, Travagli JP, Ricard M, Schlumberger M. Is diagnostic iodine-131 scanning useful after total thyroid ablation for differentiated thyroid cancer? J Clin Endocrinol Metab. 2000;85(1):175-8

45. David A, Blotta A, Rossi R, Zatelli MC, Bondanelli M, Roti E, et al. Clinical value of different responses of serum thyroglobulin to recombinant human thyrotropin in the follow-up of patients with differentiated thyroid carcinoma. Thyroid. 2005;15(2):267-73.

46. Baudin E, Do Cao C, Cailleux AF, Leboulleux S, Travagli JP, Schlumberger M. Positive predictive value of serum thyroglobulin levels, measured during the first year of follow-up after thyroid hormone withdrawal, in thyroid cancer patients. J Clin Endocrinol Metab. 2003;88(3):1107-11.

47. Spencer CA, Bergoglio LM, Kazarosyan M, Fatemi S, LoPresti JS Clinical impact of thyroglobulin $(\mathrm{Tg})$ and $\mathrm{Tg}$ autoantibody method differences on the management of patients with differentiated thyroid carcinomas. J Clin Endocrinol Metab. 2005;90(10):5566-75.

48. Pacini F, Molinaro E, Castagna MG, Agate L, Elisei R, Ceccarelli C, et al. Recombinant human thyrotropin-stimulated serum thyroglobulin combined with neck ultrasonography has the highest sensitivity in monitoring differentiated thyroid carcinoma. J Clin Endocrinol Metab. 2003;88(8):3668-73.

49. Leboulleux S, Girard E, Rose M, Travagli JP, Sabbah N, Caillou B, et al. Ultrasound criteria of malignancy for cervical lymph nodes in patients followed up for differentiated thyroid cancer. J Clin Endocrinol Metab. 2007:92(9):3590-4. 
50. LielY. Preparation for radioactive iodine administration in differentiated thyroid cancer patients. Clin Endocrinol (Oxf). 2002;57(4):523-7.

51. Golger A, FridmanTR, Eski S, Witterick IJ, Freeman JL, Walfish PG. Three-week thyroxine withdrawal thyroglobulin stimulation screening test to detect low-risk residual/recurrent well-differentiated thyroid carcinoma. J Endocrinol Invest. 2003;26(10):1023-31.

52. Haugen BR, Pacini F, Reiners $C$, Schlumberger M, Ladenson PW, Sherman $\mathrm{Sl}$, et al. A comparison of recombinant human thyrotropin and thyroid hormone withdrawal for the detection of thyroid remnant or cancer. J Clin Endocrinol Metab. 1999;84(11):3877-85.

53. Helal BO, Merlet P, Toubert ME, Franc B, Schvartz C, Gauthier-Koelesnikov $\mathrm{H}$, et al. Clinical impact of (18)F-FDG PET in thyroid carcinoma patients with elevated thyroglobulin levels and negative (131)I scanning results after therapy. J Nucl Med. 2001;42(10):1464-9.

54. Chin BB, Patel P, Cohade C, Ewertz M, WahI R, Ladenson P. Recombinant human thyrotropin stimulation of fluoro-D-glucose positron emission tomography uptake in well-differentiated thyroid carcinoma. J Clin Endocrinol Metab. 2004;89(1):91-5.

55. Schlumberger M, Mancusi F, Baudin E, Pacini F. 1311 therapy for elevated thyroglobulin levels. Thyroid. 1997;7(2):273-6.

56. Schlumberger M, Tubiana M, De Vathaire F, Hill C, Gardet P, Travagli JP, et al. Long-term results of treatment of 283 patients with lung and bone metastases from differentiated thyroid carcinoma. J Clin Endocrinol Metab. 1986;63(4):960-7.

57. Schlumberger M, Hitzel A, Toubert ME, Corone C, Troalen F, Schlageter $\mathrm{MH}$, et al. Comparison of seven serum thyroglobulin assays in the follow-up of papillary and follicular thyroid cancer patients. J Clin Endocrinol Metab. 2007;92(7):2487-95.

58. Smallridge RC, Meek SE, Morgan MA, Gates GS, FoxTP, Grebe S, et al. Monitoring thyroglobulin in a sensitive immunoassay has comparable sensitivity to recombinant human tsh-stimulated thyroglobulin in follow-up of thyroid cancer patients. J Clin Endocrinol Metab. 2007;92(1):82-7.

59. Maciel RM. [Will the thyroglobulin assay with lower functional sensitivity whilst the patients are on L-T4 treatment replace the TSH-stimulated thyroglobulin assay in the follow-up of patients with differentiated thyroid cancer?] Arq Bras Endocrinol Metabol. 2007;51(5):862-6.

60. de Keizer B, Brans B, Hoekstra A, Zelissen PM, Koppeschaar HP, Lips CJ, et al. Tumour dosimetry and response in patients with metastatic differentiated thyroid cancer using recombinant human thyrotropin before radioiodine therapy. Eur J Nucl Med Mol Imaging. 2003;30(3):367-73.

61. Pitoia F, Tamer EE, Schere DB, Passerieu M, Bruno OD, Niepomniszcze $\mathrm{H}$. Usefulness of recombinant human TSH aided radioio- dine doses administered in patients with differentiated thyroid carcinoma. Medicina (B Aires). 2006;66(2):125-30.

62. Luster M, Lippi F, Jarzab B, Perros P, Lassmann M, Reiners C, et al. rhTSH-aided radioiodine ablation and treatment of differentiated thyroid carcinoma: a comprehensive review. Endocr Relat Cancer. 2005;12(1):49-64.

63. Jentzen W, Freudenberg L, Eising EG, Sonnenschein W, Knust J, Bockisch A. Optimized 124I PET dosimetry protocol for radioiodine therapy of differentiated thyroid cancer. J Nucl Med. 2008;49(6):1017-23.

64. Koong SS, Reynolds JC, Movius EG, Keenan AM, Ain KB, Lakshmanan MC, et al. Lithium as a potential adjuvant to ${ }^{131}$ I therapy of metastatic, well differentiated thyroid carcinoma. J Clin Endocrinol Metab. 1999;84(3):912-6.

65. Shimaoka K, Schoenfeld DA, DeWys WD, Creech RH, DeConti R. A randomized trial of doxorubicin versus doxorubicin plus cisplatin in patients with advanced thyroid carcinoma. Cancer. 1985;56(9):2155-60.

66. Pennell NA, Daniels GH, Haddad RI, Ross DS, EvansT, Wirth LJ, et al. A phase II study of gefitinib in patients with advanced thyroid cancer. Thyroid. 2008;18(3):317-23.

67. Sherman SI, Wirth LJ, Droz JP, Hofmann M, Bastholt L, Martins RG, et al. Motesanib Cancer Study Group. Motesanib Diphosphate in progressive differentiated thyroid cancer. N Engl J Med. 2008;3(1):31-42.

68. Gupta-Abramson V, Troxel AB, Nellore A, Puttaswamy K, Redlinger $\mathrm{M}$, Ransone $\mathrm{K}$, et al. Phase II trial of sorafenib in advanced thyroid cancer. J Clin Oncol. 2008;26(29):4714-9.

69. Cohen EE, Rosen LS, Vokes EE, Kies MS, Forastiere AA, Worden FP, et al. Axitinib is an active treatment for all histologic subtypes of advanced thyroid cancer: results from a phase II study. J Clin Oncol. 2008;26(29):4708-13.

70. Ain KB, Lee C, Williams KD. Phase II trial of thalidomide for therapy of radiodine-unresponsive and rapidly progressive thyroid carcinomas. Thyroid. 2007;17(7):663-70.

71. Hung W, Sarlis NJ. Current controversies in the management of pediatric patients with well-differentiated nonmedullary thyroid cancer: a review. Thyroid. 2002;12(8):683-702.

72. Iorcansky S, Herzovich V, Qualey RR, Tuttle RM. Serum thyrotropin (TSH) levels after recombinant human TSH injections in children and teenagers with papillary thyroid cancer. J Clin Endocrinol Metab. 2005;90(12):6553-5.

73. Vini L, Hyer S, Pratt B, Harmer C. Management of differentiated thyroid cancer diagnosed during pregnancy. Eur $\mathrm{J}$ Endocrinol. 1999;140(5):404-6. 